O. V. Bogomaz ${ }^{1,2, *}$, M. O. Shulha ${ }^{1,2}$, D. V. Kotov ${ }^{1,2}$, T. G. Zhivolup ${ }^{1,2}$, A. V. Koloskov ${ }^{3,2}$, A. V. Zalizovski ${ }^{2,3,4}$, S. B. Kashcheyev ${ }^{3}$, A. I. Reznychenko ${ }^{3}$, M. R. Hairston ${ }^{5}$, V. Truhlik ${ }^{6}$

${ }^{1}$ Institute of Ionosphere of the National Academy of Sciences of Ukraine, 16 Kyrpychova Str., Kharkiv, 61001, Ukraine

${ }^{2}$ State Institution National Antarctic Scientific Center, Ministry of Education and Science of Ukraine, 16 Taras Shevchenko Blvd., Kyiv, 01601, Ukraine

${ }^{3}$ Institute of Radio Astronomy of the National Academy of Sciences of Ukraine, 4 Mystetstv Str., Kharkiv, 61002, Ukraine

${ }^{4}$ Space Research Centre of Polish Academy of Sciences, 18A Bartycka Str., Warsaw, 00-716, Poland

${ }^{5}$ William B. Hanson Center for Space Sciences, University of Texas at Dallas, P.O. Box 830688 FO22 Richardson, TX 75083-0688, USA

${ }^{6}$ Institute of Atmospheric Physics of the Czech Academy of Sciences, Bocni II/1401, 14100, Prague, Czech Republic

* Corresponding author: o.v.bogomaz1985@gmail.com

\title{
Ionosphere over Ukrainian Antarctic Akademik Vernadsky station under minima of solar and magnetic activities, and daily insolation: case study for June 2019
}

\begin{abstract}
We present ionospheric observational results obtained over Ukrainian Antarctic Akademik Vernadsky station. Ionospheric parameters (peak electron density and height, electron density and electron and ion temperatures in the topside) during the period near the local winter solstice in the Southern Hemisphere (June 28-29, 2019) are considered. The main objective is to show distinctive features of variations in ionospheric parameters during a prolonged period with very low solar and magnetic activities, and minimal daily insolation. Methods. F2 layer peak electron density and height were calculated from ionograms obtained with ionosonde installed at the station with subsequent profile inversion. Defense Meteorological Satellite Program (DMSP) and Swarm data acquired over the station are used as well. Diurnal variations of electron density, and electron and ion temperatures at the altitude of the satellites' orbits were calculated using a set of sub-models of the International Reference Ionosphere-2016 (IRI-2016) model. Results. We found a very good agreement between the observed and model variations of F2 layer peak electron density. Significant (by $\sim 2$ times) nighttime enhancement of electron density was observed on June 29. Electron density models show the similar increase of the density at the same time interval but this enhancement is much more smoothed comparing with the observations. Peak height values obtained using ionosonde are very close to ones calculated with the IRI-2016 sub-models. Satellite data are in a good consistency with the IRI model predictions, especially for electron density obtained by Swarm satellite. Conclusions. Multi-instrumental observations revealed a number of unique features of the ionosphere over Antarctic Peninsula under minima of solar and magnetic activities, and daily insolation.
\end{abstract}

Keywords: electron and ion temperatures, electron density, F2 layer peak height, ionosonde, reference model of ionosphere, satellite.

Cite: Bogomaz O. V., Shulha M. O., Kotov D. V., Zhivolup T. G., Koloskov A. V., Zalizovski A. V., Kashcheyev S. B., Reznychenko A. I., Hairston M. R., Truhlik V. Ionosphere over Ukrainian Antarctic Akademik Vernadsky station under minima of solar and magnetic activities, and daily insolation: case study for June 2019. Ukrainian Antarctic Journal, 2019. № 2 (19), 84-93. 


\section{INTRODUCTION}

Investigation of ionosphere over Antarctica is an important part of global geospace research (e.g., Rodger et al., 1989). Since Antarctica is a high-latitude region, this is a really good place to study the effects of magnetosphere-ionosphere coupling, especially during the space weather extreme events. However, extremely quiet magnetic conditions are also of great interest for scientists developing predictive models of ionosphere-plasmasphere system.

For many years, ionosphere observations have been carried out at Ukrainian Antarctic Akademik Vernadsky station (Akademik Vernadsky station) located at $65.25^{\circ} \mathrm{S}, 295.75^{\circ} \mathrm{E}$ using various techniques, including ionosonde sounding (Foppiano, 2016). The most complete picture of the state of the ionosphere and the processes occurring in it is given by multi-instrumental measurements together with modeling. An example of such research is the study of ionospheric response to weak geomagnetic storm of March 21-23, 2017 (Shulha et al., 2019). Data from two ionosondes (at Akademik Vernadsky station and located near the magnetically conjugated region, Wallops Island) and satellite data have been used for analysis of such ionosphere parameters as F2 layer peak electron density, peak height, and electron temperature. Simulations with the Field Line Interhemispheric Plasma (FLIP) model were carried out to establish the physical mechanisms responsible for changes in the observed electron density caused by the storm.

In contrast, this paper is focused on the investigation of variations of ionosphere parameters during prolonged period with very low solar and magnetic activities as well as with minimal daily insolation. Period of June 28-29, 2019 was found to be appropriate for this study.

\section{METHODS AND TOOLS}

Ionospheric sounding at Faraday-Vernadsky station was started at the late 1950-s. The main research tool used in this study was IPS-42 ionosonde installed at Faraday station (since 1996 Akademik Vernadsky station) in 1983. It was permanently used in regime of
15 minutes sounding (Zalizovski et al., 2018). IPS-42 was designed by the Ionospheric Prediction Service of Australia in 1974 and has the following characteristics (Table) (Broom, 1984).

Digital ionograms are available since 2001 (Koloskov et al., 2019). Each binary file contains a monochrome image with $575 \times 512$ resolution. To view this image and manually mark traces on it, IonogramViewer2 program developed in the Institute of Ionosphere was modified. A screenshot of the program with loaded ionogram is shown in Fig. 1.

Digits at the left top corner of the ionogram mean ionosonde serial number (4231), year without century (19), day of year (180) and local time (14:30). IonogramViewer2 identifies file format automatically and then reads the file content, recognizes all digits, and fills fields at the right panel ("Parameters"). The digits have good quality and they are almost fixed on the ionogram. Thus, there is no need in artificial neural networks for the digits recognition and matching a pattern algorithm is successfully used. If serial number equals 4231, parameters fields are filled by values valid for ionosonde installed at Akademik Vernadsky station (latitude is $-65.25^{\circ}$, longitude is $295.75^{\circ}$, electron gyro-frequency is $0.97 \mathrm{MHz}$, dip angle is $-59^{\circ}$ ). Local time is used. Sunspot number is loaded from file provided by Solar Influences Data Analysis Center (Belgium). Critical frequencies and traces of F2, F1 and E layers are manually scaled by user and saved to text file used for electron density profile inversion using NHPC program developed in the University of Massachusetts Lowell (Huang, Reinisch, 1996). As a result, temporal variations of F2 layer

\section{Table. Main characteristics of the IPS-42 ionosonde}

\begin{tabular}{|l|c|}
\hline \multicolumn{1}{|c|}{ Characteristic } & Value \\
\hline Frequency range & $1-22.6 \mathrm{MHz}$ \\
Number of frequencies & 576 \\
Frequency sweep configuration & Logarithmic \\
Transmitter pulse power output & $5 \mathrm{~kW}$ \\
Transmitter pulse width & $41.7 \mu \mathrm{s}$ \\
Maximum virtual height range & $800 \mathrm{~km}$ \\
\hline
\end{tabular}




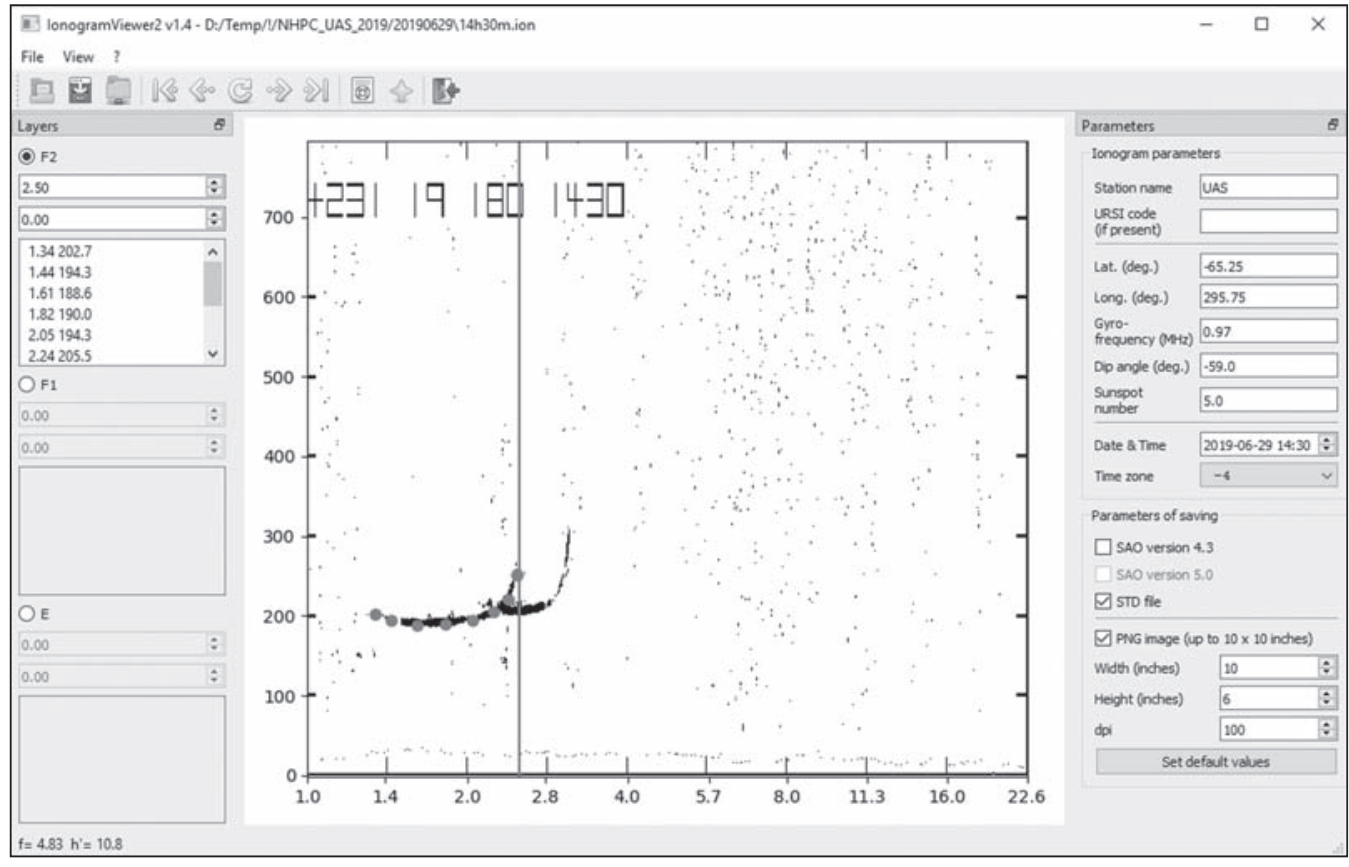

Fig. 1. Window of the IonogramViewer2 program with an ionogram obtained on June 29, 2019 at 18:30 UT. Manually scaled F2 layer trace is marked using dots, F2 layer frequency $f_{0} \mathrm{~F}_{2}$ is marked using vertical line

peak electron density $N_{m} \mathrm{~F}_{2}$ and F2 layer peak height $h_{m} \mathrm{~F}_{2}$ are obtained.

Satellite data used in the study are electron density $N_{e}$, electron $\left(T_{e}\right)$ and ion $\left(T_{i}\right)$ temperatures.

Defense Meteorological Satellite Program (DMSP) spacecraft have Special Sensor for Ions, Electrons and Scintillation (SSIES) instrument package installed. SSIES measures the electron density, as well as ion and electron temperatures (Rich, 1994; Garner et al., 2010; Hairston et al., 2018).

A satellite constellation Swarm consists of three identical spacecraft. Swarm Alpha and Swarm Charlie (flying at the altitude $\sim 455 \mathrm{~km}$ ) and Swarm Bravo (flying at the altitude $\sim 520 \mathrm{~km}$ ) have Electric Field Instrument which measures electron and ion temperatures, as well as plasma density (Olsen, Floberghagen, 2018).

Time moments of the satellites passes over Akademik Vernadsky station were found with Sat_Pass program developed in the Institute of Ionosphere.

All the observational data are compared with predictions of International Reference Ionosphere (IRI-
2016) model (Bilitza et al., 2017). IRI model is an empirical standard model of the ionosphere based on available and reliable data sources specifying climatology of electron density, ion composition, electron temperature, and ion temperature in the altitude range from $50 \mathrm{~km}$ to $2000 \mathrm{~km}$.

In the present work, the IRI model options for the electron density (NeQuick and IRI-2001 Corr), the height of F2 layer peak (AMTB-2013 and SHU-2015), and temperature (TBT-2012+SA) models were used.

NeQuick model is an ionospheric electron density model particularly designed for trans-ionospheric applications which allows calculating the electron density distribution in both the bottomside and topside of the ionosphere (Nava et al., 2008; Radicella, 2009). To describe the electron density of the ionosphere up to the F2 layer peak, NeQuick uses a profile formulation which includes semi-Epstein layers with a height-dependent thickness parameter empirically determined (Hochegger et al., 2000; Leitinger et al., 2005).

AMTB-2013 model is based on data from 26 digisonde stations from the Global Ionosphere Radio ISSN 1727-7485. Ukrainian Antarctic Journal. 2019, № 2(19) 

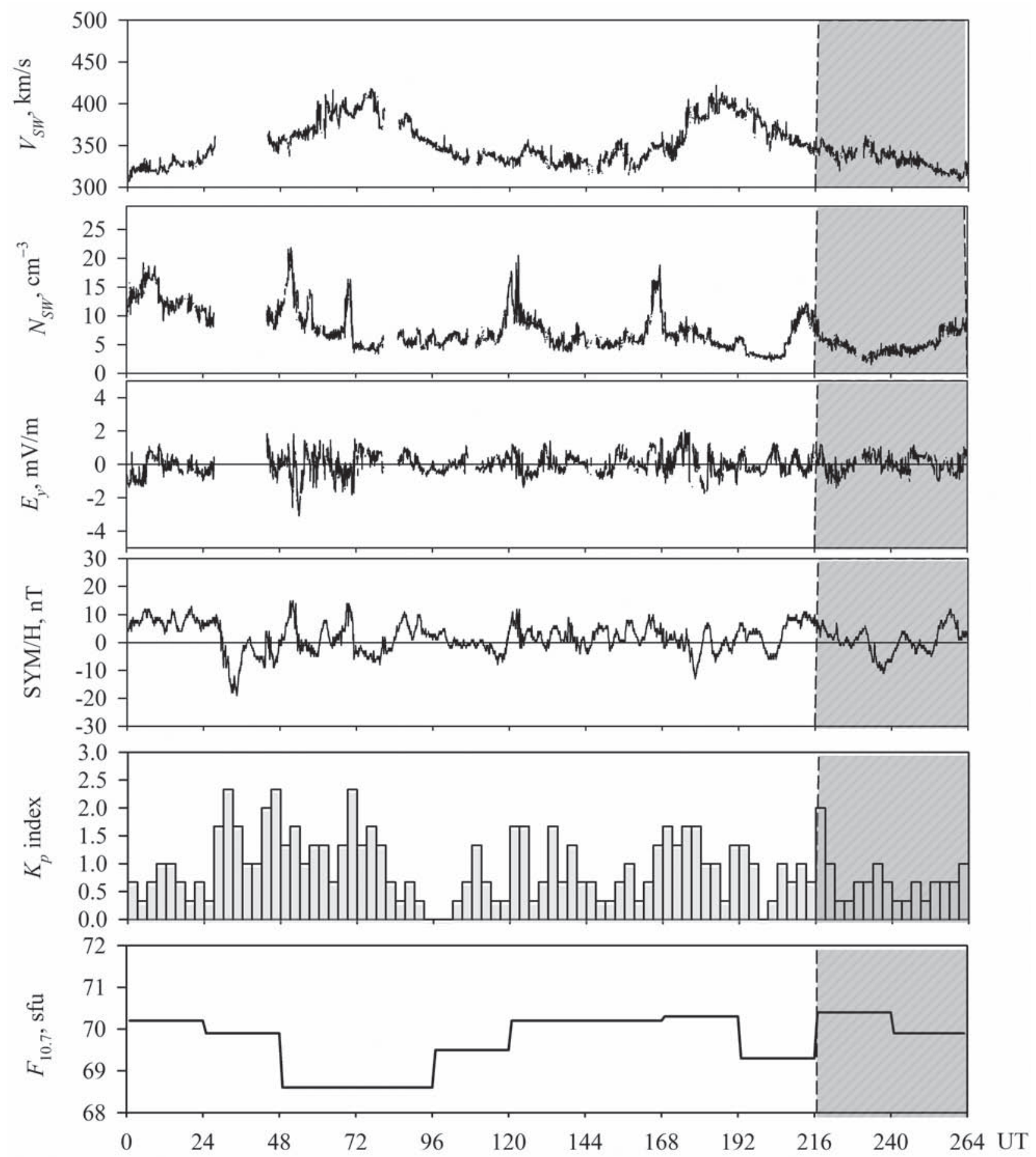

Fig. 2. Variations of solar wind velocity $\left(V_{S W}\right)$, proton density $\left(N_{S W}\right)$, zonal component of magnetospheric electric field $\left(E_{y}\right)$, $S Y M / H$ index, 3-hour $K_{p}$ index, and daily solar activity $F_{10.7}$ index for June 19-29, 2019. The last two days (June 28-29, 2019) shown by filled area are an observation period 


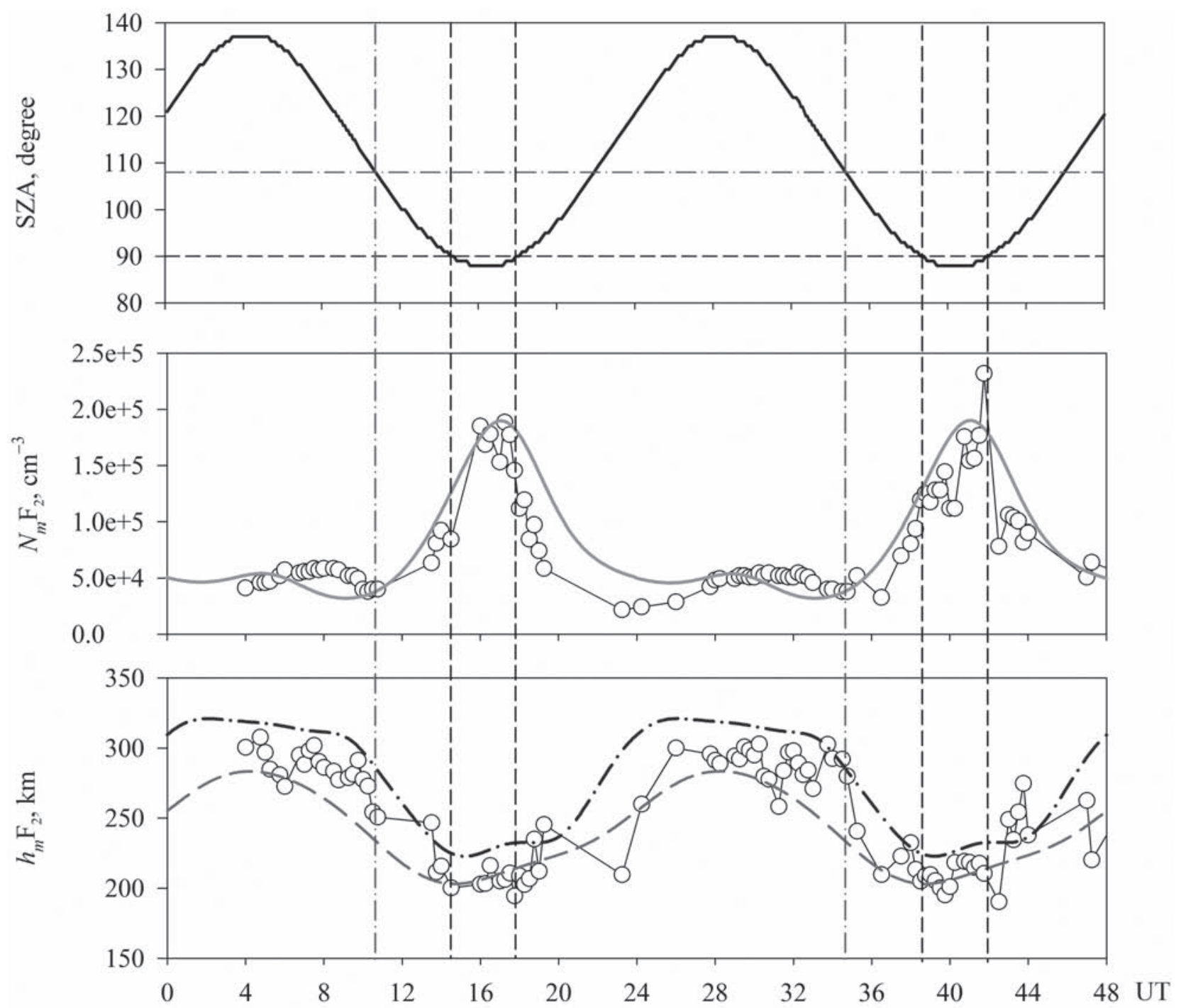

Fig. 3. Variations of $\mathrm{F} 2$ layer peak height $\left(h_{m} \mathrm{~F}_{2}\right)$ and electron density $\left(N_{m} \mathrm{~F}_{2}\right)$ observed by the ionosonde of Akademik Vernadsky station (open circles) and IRI-2016 model calculations (lines). The solid orange line shows $N_{m} \mathrm{~F}_{2}$ (URSI option). The dashed and dash-dotted lines show $h_{m} \mathrm{~F}_{2}$ from AMTB-2013 and SHU-2015 models respectively. On the top panel, solar zenith angle (SZA) variation is shown. Dashed vertical lines denote the time moments when SZA equals $90^{\circ}$. Dash-dotted vertical line shows a moment of an astronomical dawn

Observatory (GIRO) network (Reinisch, Galkin, 2011). The data cover the various periods of solar activity (spanning from 1998 to 2006). The spherical harmonic technique is applied in AMTB-2013 to model the $h_{m} \mathrm{~F}_{2}$ at a global scale for quiet geomagnetic conditions (Altadill et al., 2013).

SHU-2015 model is based on the ionospheric radio occultation data provided by CHAMP (from 2001 to 2008), GRACE (from 2007 to 2011) and COSMIC (from 2006 to 2012) satellite missions as well as the digisonde-derived electron density vertical profiles (Shubin, 2015). SHU-2015 uses the spherical harmonics decomposition to model $h_{m} \mathrm{~F}_{2}$.

TBT-2012+SA model is a new version of the electron temperature model. The model represents a continuation and improvement of previously developed $T_{e}$ model (Truhlik et al., 2000) and it is based on bigger volume of data and additionally includes a soISSN 1727-7485. Ukrainian Antarctic Journal. 2019, № 2(19) 

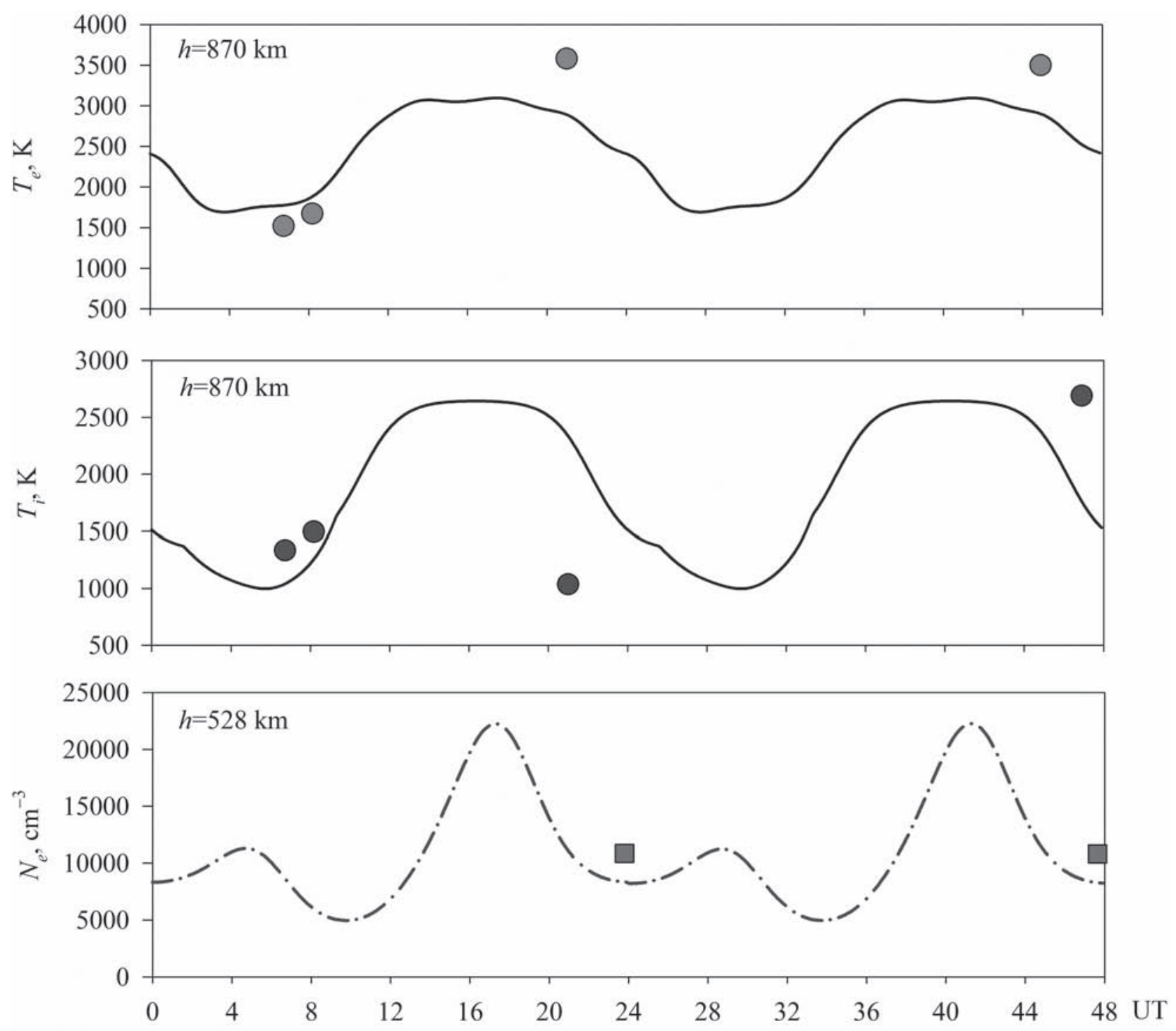

Fig. 4. Diurnal variations of $T_{e}$ and $T_{i}$ at the altitude of the DMSP satellites (two top panels) calculated for June 28-29, 2019 with IRI-2016/TBT-2012+SA model (lines) and DMSP data (circles). Bottom panel shows the electron density $N_{e}$ at the altitude of the Swarm Bravo satellite (squares). Dash-dotted line shows $N_{e}$ at $528 \mathrm{~km}$ from the NeQuick model. The DMSP and Swarm data points are plotted with UT, which corresponds at Akademik Vernadsky station to the same magnetic local time as it was at the points of the satellite passes

lar activity dependence of the electron temperature (Truhlik et al., 2012).

\section{RESULTS AND DISCUSSION}

For this study, magnetically quiet period near the local winter solstice in the Southern hemisphere was selected (June 28-29, 2019) which was preceded by $\sim 10$ days of very low magnetic activity. Fig. 2 shows the main solar wind parameters and indices of magnetic activity. The solar wind speed $\left(V_{s w}\right)$ did not exceed $420 \mathrm{~km} / \mathrm{s}$ for the period of observations. The short-time enhancements in proton density $\left(N_{s w}\right)$ occurred from time to time, indicating that weak coronal mass ejections events took place. The dawn-todusk interplanetary electric field $\left(E_{y}\right)$ was varying 
from -2 to $+2 \mathrm{mV} / \mathrm{m}$ during the entire considered period. The 3 -hour $K_{p}$ index ranged from 0 to $2+$. Another important feature is that the minimum of $S Y M / H$ index was higher than $-20 \mathrm{nT}$ that implies the absence of any significant disturbances of ring current. The solar activity was stable during the investigated period with daily $F_{10.7}$ of $\sim 70$ solar flux units.

Peak height $h_{m} \mathrm{~F}_{2}$ and electron density $N_{m} \mathrm{~F}_{2}$ obtained from ionograms are shown in Fig. 3. On the top panel of the figure, a variation of solar zenith angle (SZA) obtained using FLIP model is shown. An important point is that ionosphere over Akademik Vernadsky station is sunlit during very short periods (less than 4 hours, marked by vertical lines) and even at that intervals, SZA value is not much less than $90^{\circ}$. Generally speaking, insolation time has its annual minimum at the days of interest. Obviously, this leads to very low electron density values even during the daytime. Values of $N_{m} \mathrm{~F}_{2}$ generally do not exceed $2 \times 10^{5} \mathrm{~cm}^{-3}$. Additional green dash-dotted vertical lines mark astronomical dawn and it is clearly seen that $N_{m} \mathrm{~F}_{2}$ rise begins when SZA is higher than $90^{\circ}$ (at $108^{\circ}$ ). At the same time moment, rapid decrease of $h_{m} \mathrm{~F}_{2}$ is seen.

Significant (by a factor of $\sim 2$ ) nighttime enhancement of $N_{m} \mathrm{~F}_{2}$ seen on June 29 is likely caused by the plasma flux directed from the plasmasphere to the ionosphere. This $N_{m} \mathrm{~F}_{2}$ enhancement implies the fullness of plasmaspheric flux tube that is not strange since there was prolonged magnetically quiet period before.

There is a very good agreement between the observed $N_{m} \mathrm{~F}_{2}$ variation and IRI-2016 model predictions. In particular, IRI model shows the nighttime enhancement but it is not as clear as in the observation. The likely reason is that IRI $N_{m} \mathrm{~F}_{2}$ is built on the data collected during the period with moderately enhanced magnetic activity when the flux tube could be partially emptied that not provided strong enough downward nighttime plasma fluxes (Kotov et al., 2018).

The observed variation of $h_{m} \mathrm{~F}_{2}$ lies between the variations provided by AMTB-2013 and SHU-2015 models. Uncertainties in $h_{m} \mathrm{~F}_{2}$ estimates can reach several tens of kilometers making it is impossible to decide which model is better. Similar researches made by Zhao et al. (2017) and Moro et al. (2019) show that SHU-2015 option when using IRI-2016 to model $h_{m} \mathrm{~F}_{2}$ over the Chinese and Brazilian regions is preferred. On the other hand, this conclusion is in sharp contrast with the results of an investigation carried out by Oyekola (2019). AMTB-2013 gives less deviation of $h_{m} \mathrm{~F}_{2}$ prediction for Ouagadougou $\left(12.4^{\circ} \mathrm{N}\right.$, $358.5^{\circ} \mathrm{E}$; dip latitude: $\left.1.5^{\circ} \mathrm{N}\right)$, Burkina Faso station. Deficiency of morning and evening values of the peak electron density and height partly rise from the presence of sporadic $\mathrm{E}_{\mathrm{s}}$ layer, low level of the received signal or distortions of ionogram traces that causes difficulties in their interpretation.

The comparison of the observations with IRI model in the topside ionosphere is shown in Fig. 4. For this study, DMSP and Swarm satellite data in the longitudinal sector of $\pm 15^{\circ}$ and latitudinal sector of $\pm 1^{\circ}$ near the Akademik Vernadsky station were selected.

Both electron density data points obtained with Swarm near local midnight agree well with NeQuick model at $528 \mathrm{~km}$. It should be noted that NeQuick model shows weak nighttime increase of electron density at approximately the same time as Akademik Vernadsky station and IRI $N_{m} \mathrm{~F}_{2}$ model results. This means that NeQuick reflects the ionospheric effects of the downward nighttime plasma fluxes from the plasmasphere.

DMSP data for electron temperature is in excellent agreement with IRI-2016/TBT-2012+SA model for both nighttime and daytime conditions. Good agreement is seen also for DMSP ion temperatures and $T_{i}$ model of IRI at night. Model-data differences for dusk time reached $50 \%$.

Comparison of DMSP, Swarm and other satellites electron densities with the results of ionosonde observations and IRI-2016 model predictions, as well as simulation using FLIP model for Akademik Vernadsky station and its geomagnetic conjugate point during periods with different magnetic conditions and solar activity is suggested as a future study.

\section{CONCLUSIONS}

The state of ionosphere over Ukrainian Antarctic Akademik Vernadsky station under minimal solar and magnetic activities and the lowest daily insolation ISSN 1727-7485. Ukrainian Antarctic Journal. 2019, № 2(19) 
(near the local winter solstice) was investigated. Studied period of June 28-29, 2019 was preceded by period with similar quiet conditions of at least 9 days duration. IPS-42 ionosonde installed at the station, DMSP and Swarm satellites, and the set of various sub-models of International Reference Ionosphere2016 model were used in the study. The main results are the following.

1. Minimal daily insolation (ionosphere illuminated by the sun less than 4 hours per day with minimal zenith angle of $\sim 88^{\circ}$ ) leads to very low F2 layer peak electron density $N_{m} \mathrm{~F}_{2}$ even near the local noon $\left(\sim 2 \times 10^{5} \mathrm{~cm}^{-3}\right)$.

2 . There is a good agreement between the observed $N_{m} \mathrm{~F}_{2}$ variation and IRI-2016 model predictions both qualitatively and quantitatively.

3. A factor of $\sim 2$ nighttime enhancement of $N_{m} \mathrm{~F}_{2}$ was observed. The presence of this phenomenon is likely an indicator of presence of plasma flux directed from the plasmasphere to the ionosphere during the night. This, in turn, implies the fullness of plasmaspheric flux tube. Both the $N_{m} \mathrm{~F}_{2}$ (URSI) and topside electron density (NeQuick) models of IRI-2016 model show the similar increase of the density at the same time interval but IRI $N_{m} \mathrm{~F}_{2}$ enhancement is much more smoothed comparing with the observations.

4. The observed variation of $h_{m} \mathrm{~F}_{2}$ is between the variations provided by AMTB-2013 and SHU-2015 models of IRI-2016 model. Both the IRI $h_{m} \mathrm{~F}_{2}$ models show a good agreement with the observations, maximal deviation doesn't exceed several tens of kilometers.

5. Satellite data obtained in the close proximity to the coordinates of Akademik Vernadsky station are generally in good agreement with IRI sub-models, especially for electron density (Swarm observations, TBT-2012+SA model of IRI-2016) and electron temperature (DMSP observations, NeQuick model of IRI-2016).

Acknowledgments and data. The authors are grateful to the State Institution National Antarctic Scientific Center, Ministry of Education and Science of Ukraine for supporting this research (0119U003049 "Investigation of seasonal features of ionospheric effects of storms in geospace over Antarctica and Ukraine", and 0119U103575). M.O. Shulha and O.V. Bogomaz are supported also by project $0119 \mathrm{U} 100032$ "Investigations of long-term changes of the plasmasphere: new results for security into the space and on Earth" funded by the Ministry of Education and Science of Ukraine. The work is partially supported by project 0116 U000035 of the National Academy of Sciences of Ukraine. V. Truhlik was supported, in part, by grant LTAUSA17100 of the Ministry of Education, Youth and Sports of the Czech Republic. Authors thank P.G. Richards for the FLIP model laptop version. IonogramViewer2 and Sat_Pass programs can be downloaded from repositories on GitHub (https:// github.com/Albom/IonogramViewer2 and https:// github.com/Albom/Sat_Pass). NHPC program can be downloaded from UMass Lowell Space Science Lab website (https://ulcar.uml.edu/SoftwareUtilities/ NHPC/NHPC430.ZIP). Swarm data are provided by the European Space Agency and can be downloaded from https://swarm-diss.eo.esa.int/. We acknowledge Open Madrigal Initiative for providing DMSP data on the http://cedar.openmadrigal.org link and personally thank Patricia Doherty (Boston College). Space weather indices were taken from OMNIWeb (https://omniweb.gsfc.nasa.gov/form/ omni_min.html) and National Oceanic and Atmospheric Administration Space Weather Prediction Center (NOAA SWPC) FTP server (ftp://ftp.swpc.noaa.gov/ pub/indices/old_indices/). International Reference Ionosphere (2016) online version is available on Community Coordinated Modeling Center website (https://ccmc.gsfc.nasa.gov/modelweb/models/ iri2016_vitmo.php). Sunspot number file used in IonogramViewer2 program is provided by Solar Influences Data Analysis Center (a part of the Royal Observatory of Belgium) and can be downloaded from SIDC website (http://www.sidc.be/silso/DATA/ SN_d_tot_V2.0.txt).

\section{REFERENCES}

Altadill, D., Magdaleno, S., Torta, J.M., Blanch, E. 2013. Global empirical models of the density peak height and of the equivalent scale height for quiet conditions. Advances in Space Research, 52 (10), 1756-1769. https://www.doi.org/10.1016/ j.asr.2012.11.018. 
Bilitza, D., Altadill, D., Truhlik, V., Shubin, V., Galkin, I., Reinisch, B., Huang, X. 2017. International Reference Ionosphere 2016: From ionospheric climate to real-time weather predictions. Space Weather-the International Journal of Research and Applications, 15 (2), 418-429. https://doi.org/ 10.1002/2016SW001593.

Broom, S.M. 1984. A new ionosonde for Argentine Islands ionospheric observatory, Faraday Station. British Antarctic Survey Bulletin, 62, 1-6.

Foppiano, A.J., Won, Y.I., Torres, X.A., Flores, P.A., Veloso, A.D., Arriagada, M.A. 2016. Ionosonde and optical determinations of thermospheric neutral winds over the Antarctic Peninsula. Advances in Space Research, 58 (10), 2026-2036.

Garner, T.W., Taylor, B.T., Gaussiran, T.L., Coley, W.R., Hairston, M.R., Rich, F.J. 2010. Statistical behavior of the topside electron density as determined from DMSP observations: A probabilistic climatology. Journal of Geophysical Research: Space Physics, 115 (A7). https://doi.org/10.1029/ 2009 JA014695.

Hairston, M.R., Mrak, S., Coley, W.R., Burrell, A., Holt, B., Perdue, M., Depew, M., Power, R. 2018. Topside ionospheric electron temperature observations of the 21 August 2017 eclipse by DMSP spacecraft. Geophysical Research Letters, 45 (15), 7242-7247. https://doi.org/10.1029/2018GL07 7381.

Hochegger, G., Nava, B., Radicella, S.M., Leitinger, R. 2000. A family of ionospheric models for different uses. Physics and Chemistry of the Earth, Part C: Solar, Terrestrial \& Planetary Science, 25, 307-310. https://doi.org/10.1016/ S1464-1917(00)00022-2.

Huang, X., Reinisch, B.W. 1996. Vertical electron density profiles from the Digisonde network. Adv. Space Res., 18, 121-129. https://doi.org/10.1016/0273-1177(95)00912-4.

Koloskov, O.V., Kashcheyev, A.S., Zalizovski, A.V., Kashcheyev, S.B., Budanov, O.V., Charkina, O.V., Pikulik, I.I., Lysachenko, V.M., Sopin, A.O., Reznychenko, A.I. New digital ionosonde developed for Ukrainian Antarctic station "Akademik Vernadsky". IX International Antarctic Conference dedicated to the 60th anniversary of the signing of the Antarctic Treaty in the name of peace and development of international cooperation: Physical sciences. Kyiv, 14-16 May, 2019, $166-167$.

Kotov, D.V., Richards, P.G., Truhlík, V., Bogomaz, O.V., Shulha, M.O., Maruyama, N., Hairston, M., Miyoshi, Y., Kasahara, Y., Kumamoto, A., Tsuchiya, F., Matsuoka, A., Shinohara, I., Hernández-Pajares, M., Domnin, I.F., Zhivolup, T.G., Emelyanov, L.Ya., Chepurnyy, Ya.M. 2018. Coincident Observations by the Kharkiv IS Radar and Ionosonde, DMSP and Arase (ERG) Satellites, and FLIP Model Simulations: Implications for the NRLMSISE-00 Hydrogen Density, Plasmasphere, and Ionosphere. Geophysical Research Letters, 45 (16), 8062-8071. https://doi.org/10.1029/2018GL079206.

Leitinger, R., Zhang, M.L., Radicella, S.M. 2005. An improved bottomside for the ionospheric electron density model
NeQuick. Annals of Geophysics, 48, 525-534. https://doi.org/ 10.4401/ag-3217.

Moro, J., Xu, J., Marcos De Nardin, C., Cristina Araújo Resende, L., Pereira Silva, R., Su Chen, S., Arlan da Silva Picanço, G., Zhengkuan, L., Li, H., Yan, C., Wang, C., Jorge Schuch, N. 2019. Performance of the IRI-2016 at the Brazilian low-latitude ionosphere over the South America Magnetic Anomaly during solar minimum, Ann. Geophys. Discuss., in review. https://doi.org/10.5194/angeo-2019-126.

Nava, B., Coïsson, P., Radicella, S.M. 2008. A new version of the NeQuick ionosphere electron density mode. Journal of Atmospheric and Solar-Terrestrial Physics, 70, 1856-1862. http:// doi.org/10.1016/j.jastp.2008.01.015.

Olsen, N., Floberghagen, R. 2018. Exploring Geospace from Space: the Swarm Satellite Constellation Mission. Space Res. Today, 203, 61-71. https://doi.org/10.1016/j.srt.2018.11.017.

Oyekola, O.S. 2019. Comparison of IRI-2016 model-predictions of F2-layer peak density height options with the ionosonde-derived hmF2 at the equatorial station during different phases of solar cycle. Advances in Space Research, 64 (10), 2064-2076. https://doi.org/10.1016/j.asr.2019.04.022.

Radicella, S.M. 2009. The NeQuick model genesis, uses and evolution. Annals of Geophysics, 52, 417-422. https:// doi.org/10.4401/ag-4597.

Reinisch, B.W., Galkin, I.A. 2011. Global Ionospheric Radio Observatory (GIRO), Earth, Planets and Space, 63 (4), 377-381, https://doi.org/10.5047/ eps.2011.03.001.

Rich, F.J. 1994. Users guide for the topside ionospheric plasma monitor (SSIES, SSIES-2, and SSIES-3) on spacecraft of the Defense Meteorological Satellite Program, volume 1: Technical description. (Technical report PL-TR-942187). Phillips Laboratory.

Rodger, A.S., Smith, A.J., Rycroft, M.J. 1989. Antarctic Studies of the Coupled Ionosphere-Magnetosphere System [and Discussion]. Philosophical Transactions of the Royal Society A: Mathematical, Physical and Engineering Sciences, 328 (1598), 271-287. http://doi.org/10.1098/rsta.1989.0036.

Shubin, V.N. 2015. Global median model of the F2-layer peak height based on ionospheric radio-occultation and ground-based Digisonde observations. Adv. Space Res., 56, 916928. https://doi.org/10.1016/j.asr.2015.05.029.

Shulha, M.O., Kotov, D.V., Bogomaz, O.V., Zhivolup, T.G., Koloskov, O.V., Lisachenko, V.M., Hairston, M. Multiinstrumental and modeling investigation of ionospheric response to weak geomagnetic storm of 21-23 March 2017 over the Ukrainian Antarctic station and magnetically conjugate region. IX International Antarctic Conference dedicated to the 60th anniversary of the signing of the Antarctic Treaty in the name of peace and development of international cooperation: Physical sciences. Kyiv, 14-16 May, 2019, 179-180.

Truhlik, V., Triskova, L., Smilauer, J., Afonin, V.V. 2000. Global empirical model of electron temperature in the outer ionosphere for period of high solar activity based on data of 
three Intercosmos satellites. Adv. Space Res., 25 (1), 163-169. https://doi.org/10.1016/S0273-1177(99)00914-X.

Truhlik, V., Bilitza, D., Triskova, L. 2012. A new global empirical model of the electron temperature with the inclusion of the solar activity variations for IRI. Earth, Planets and Space, 64, 531-543. https://doi.org/10.5047/eps.2011.10.016.

Zalizovski, A.V., Kashcheyev, A.S., Kashcheyev, S.B., Koloskov, A.V., Lisachenko, V.N., Paznukhov, V.V., Pikulik, I.I., Sopin, A.A., Yampolski, Yu.M. 2018. A prototype of a portable coherent ionosonde model. Space science and technology -
Kosmichna nauka i tehnologia, 24 (3), 10-22. http://doi.org/ 10.15407/knit2018.03.010.

Zhao, X., Ning, B., Zhang, M.L., Hu, L. 2017. Comparison of the ionospheric F2 peak height between ionosonde measurements and IRI2016 predictions over China. Adv. Space Res., 60, 1524-1531. http://doi.org/10.1016/ j.asr.2017. 06.056.

О. В. Богомаз $1,2, *$, М. О. Шульга ${ }^{1,2}$, Д. В. Котов ${ }^{1,2}$, Т. Г. Живолуп ${ }^{1,2}$,

О. В. Колосков ${ }^{3,2}$, А. В. Залізовський ${ }^{2,3,4}$, С. Б. Кащеєв ${ }^{3}$, А. І. Резниченко ${ }^{3}$, М. Р. Гейрстон ${ }^{5}$, В. Трухлік

${ }^{1}$ Інститут іоносфери Національної академії наук України, Міністерство освіти і науки України, вул. Кирпичова, 16, м. Харків, 61001, Україна

2 Державна установа Національний антарктичний науковий центр МОН України,

бульв. Тараса Шевченка, 16, м. Київ, 01601, Україна

${ }^{3}$ Радіоастрономічний інститут Національної академії наук України, вул. Мистецтв, 4, м. Харків, 61002, Україна

${ }^{4}$ Центр космічних досліджень Польської академії наук, вул. Бартицка, 18А, м. Варшава, 00-716, Польща

${ }^{5}$ Науковий космічний центр ім. У. Хансона, Техаський університет в Далласі, a/c 830688 FO22, м. Річардсон, штат Техас, 75083-0688, США

${ }^{6}$ Інститут фізики атмосфери Академії наук Чеської Республіки, вул. Бочни, II/1401, м. Прага, 14100 , Чехія

* Автор для кореспонденції: o.v.bogomaz1985@gmail.com

Іоносфера над Українською антарктичною станцією “Академік Вернадський” в умовах мінімумів сонячної та магнітної активності, а також добової інсоляції: дослідження в червні 2019 р.

Реферат. У статті представлені результати спостережень іоносфери над Українською антарктичною станцією “Академік Вернадський”. Розглянуто параметри іоносфери (висота максимуму шару F2 та концентрація електронів на цій висоті, концентрація електронів, температури електронів та іонів у зовнішній іоносфері) впродовж періоду поблизу локального зимового сонцестояння у Південній півкулі (28-29 червня 2019 р.). Мета роботи. Показати відмінні риси варіацій параметрів іоносфери під час тривалого періоду з дуже низькою сонячною та магнітною активністю та мінімальною добовою інсоляцією. Методи. Висота шару F2 іоносфери та концентрація електронів на цій висоті розраховувалися за даними з іонограм, які отримано за допомогою встановленого на станції іонозонду, з подальшим виконанням процедури інверсії висотних профілів концентрації електронів. Також використовувалися дані з супутників Defense Meteorological Satellite Program (DMSP) та Swarm. Добові варіації концентрації електронів, температур електронів та іонів на висотах орбіт супутників розраховувалися за допомогою низки субмоделей моделі International Reference Ionosphere-2016 (IRI-2016). Результати. Виявлено, що експериментально отримані варіації концентрації електронів у максимумі шару F2 iоносфери добре узгоджуються з модельними. Спостерігалося суттєве (приблизно у 2 рази) нічне збільшення концентрації електронів 29 червня. Моделі концентрації електронів показують подібне зростання, але більш згладжене у порівнянні 3 результатами спостережень. Значення висоти максимуму шару F2, отримані за даними іонозонду, дуже близькі до значень, розрахованих за допомогою моделі IRI-2016. Супутникові дані добре узгоджуються з прогнозами моделі, особливо для концентрації електронів, отриманої супутником Swarm. Висновки. Мультиінструментальні спостереження дозволили виявити низку унікальних особливостей іоносфери над Антарктичним півостровом в умовах мінімумів сонячної та магнітної активності, а також сонячної інсоляції.

Ключові слова: висота максимуму шару F2, довідкова модель іоносфери, іонозонд, концентрація електронів, супутник, температури електронів та іонів. 